\title{
Multifocal myeloid sarcomas: a rare presentation of AML
}

\author{
Natthapon Angsubhakorn, Attaya Suvannasankha
}

Department of Medicine, Indiana University School of Medicine, Indianapolis, Indiana, USA

\section{Correspondence to Dr Attaya Suvannasankha, asuvanna@iupui.edu}

Accepted 18 September 2017

\section{DESCRIPTION}

A 29-year-old previously healthy man presented to the hospital with a 2-month history of generalised weakness and swelling of the right eyelid. Physical examination showed ptosis of the right eye (figure 1A). In addition, he was anaemic and had had a decreased breath sound on the left lung. White cell count was 78000 cells $/ \mathrm{mm}^{3}$, haemoglobin was $5.3 \mathrm{~g} / \mathrm{dL}$ and platelet was 63000 cells $/ \mathrm{mm}^{3}$. Peripheral blood smear revealed immature circulating cells (figure 1B). Flow cytometry was positive for CD34, CD117 and CD13, compatible with acute myeloid leukaemia (AML). Whole body CAT scan demonstrated infiltrative orbital mass at right eyelid and the superior aspect of right orbit (figure 1C,D) and a pleural-based left lower lung mass with associated left pleural effusion. Cytology of pleural fluid was positive for numerous blast cells. Biopsy of retro-orbital mass was deferred due to the concern of bleeding complication. He was immediately started on an induction chemotherapy regimen consisting of idarubicin and cytarabine. Circulating blasts rapidly declined and, correspondingly, eyelid swelling and pleural effusion were diminished.
Myeloid sarcoma (MS), also called extramedullary disease of AML, or chloroma, is a rare disease, occurring in only $2 \%-8 \%$ of patients with AML. It can present as an isolated extramedullary leukaemic tumour, concurrently with AML, or at relapse. Pathobiology of MS could be related to an aberrant homing signal for the leukaemic blasts allowing for clonal expansion outside of the more common bone marrow localisation. MS is most commonly reported in the skin, bone and lymph nodes. Owing to the rarity of MS, prognostic factors in these patients remain unknown. While it has been correlated with poor prognosis in adult, the superior outcome has been observed in paediatric AML with orbital and central nervous system MS. ${ }^{1}$ Currently, recommended treatment is systemic therapy with induction regimen used in AML (combination of cytarabine and anthracyclines) in patients presenting with isolated MS or MS presenting concomitantly with AML, because of high failure rate associated with local treatment alone (88\%-100\% vs 42\%). ${ }^{2}$ Radiotherapy does not prolong overall survival but is commonly used to palliate symptoms. Orbital granulocytic sarcoma

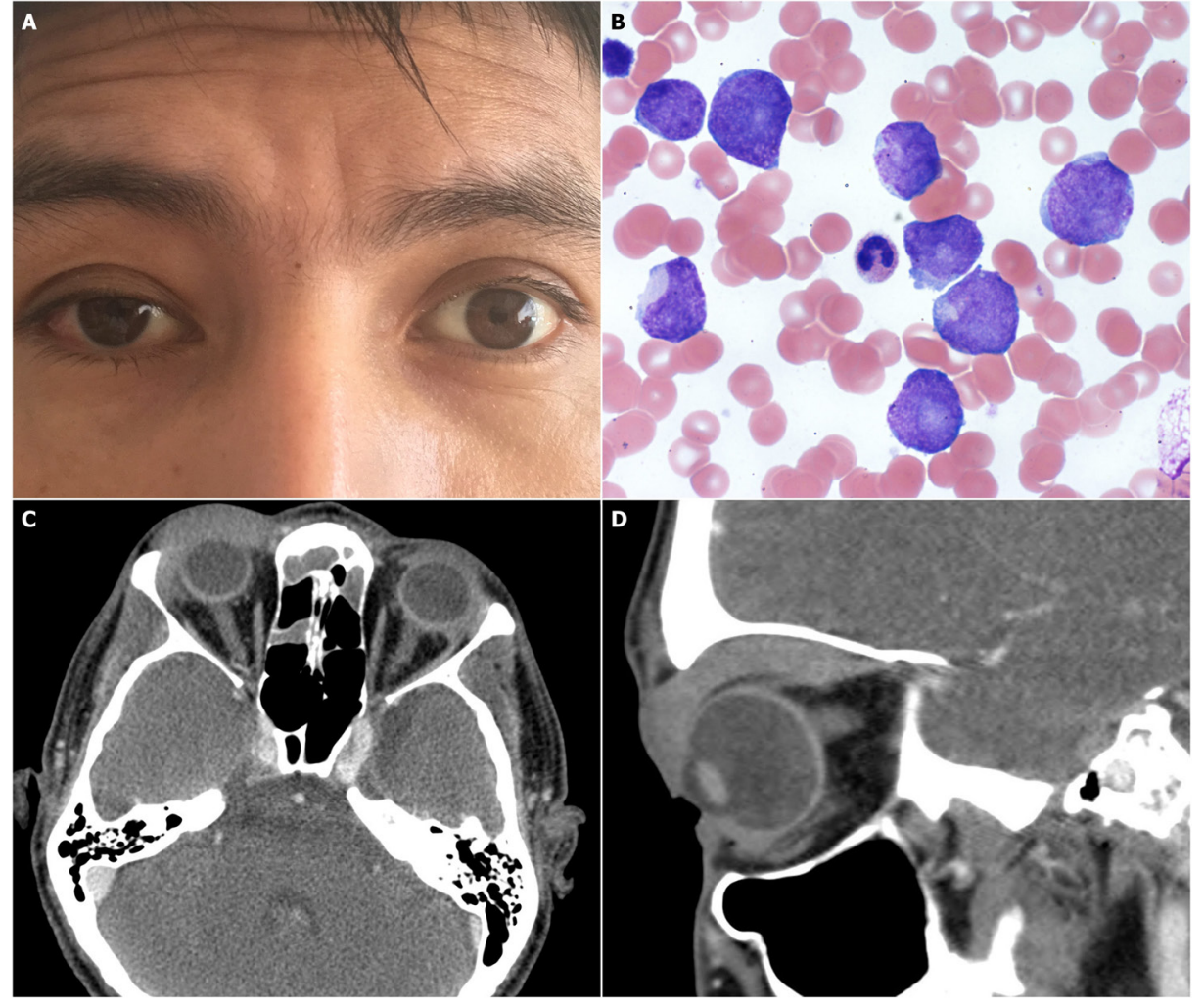

Figure 1 (A) A photograph at presentation demonstrating right eyelid swelling with ptosis. (B) Peripheral blood smear showing multiple blast cells. Axial (C) and sagittal (D) CT images demonstrating a right orbital mass. 


\section{Learning points}

- Myeloid sarcoma, a rare presentation of acute myeloid leukaemia (AML), can occur as an isolated extramedullary leukaemic tumour, concurrently with, or at relapse.

- Recommended treatment is systemic therapy with induction regimen used in AML (combination of cytarabine and anthracyclines).

- Orbital granulocytic sarcoma can progress rapidly resulting in permanent visual loss and is an oncological emergency that may require decompressive surgery or radiation.

occurs more commonly in paediatric rather than adult AML. Rapid visual loss from orbitopathy leading to compression of the optic nerve is an oncological emergency. ${ }^{3}$ Decompressive surgery and radiation have both been used successfully.
Contributors Both authors were involved in the management of the case and the manuscript preparation.

Competing interests None declared.

Patient consent Obtained.

Provenance and peer review Not commissioned; externally peer reviewed.

(c) BMJ Publishing Group Ltd (unless otherwise stated in the text of the article) 2017. All rights reserved. No commercial use is permitted unless otherwise expressly granted.

\section{REFERENCES}

1 Johnston DL, Alonzo TA, Gerbing RB, et al. Superior outcome of pediatric acute myeloid leukemia patients with orbital and CNS myeloid sarcoma: a report from the Children's Oncology Group. Pediatr Blood Cancer 2012;58:519-24.

2 Avni B, Koren-Michowitz M. Myeloid sarcoma: current approach and therapeutic options. Ther Adv Hematol 2011;2:309-16.

3 Payne C, Olivero WC, Wang B, et al. Myeloid sarcoma: a rare case of an orbital mass mimicking orbital pseudotumor requiring neurosurgical intervention. Case Rep Neurol Med 2014;2014:1-4.

Copyright 2017 BMJ Publishing Group. All rights reserved. For permission to reuse any of this content visit

http://group.bmj.com/group/rights-licensing/permissions.

BMJ Case Report Fellows may re-use this article for personal use and teaching without any further permission.

Become a Fellow of BMJ Case Reports today and you can:

- Submit as many cases as you like

- Enjoy fast sympathetic peer review and rapid publication of accepted articles

- Access all the published articles

Re-use any of the published material for personal use and teaching without further permission

For information on Institutional Fellowships contact consortiasales@bmjgroup.com

Visit casereports.bmj.com for more articles like this and to become a Fellow 